ISSN: 0213-2079 - ISSN electrónico: 2386-3889

DOI: https://doi.org/10.14201/shhmo2019412734

\title{
LA «COMPLICADA» HISTORIA DE UNA FUNDACIÓN. DOMINICAS DE LA MADRE DE DIOS DE VALLADOLID $(1550)^{1}$
}

\section{The "complicated» story of a foundation. Dominicans of the Mother of God of Valladolid (1550)}

«...hallándose con algunos vienes que Dios nuestro Señor les dio, y queriendo los emplear en servicio de su magestad movidos de la afizion y devozion que tenían a la Orden de nro. Padre Santo Domingo determinaron fundar un convento de Religiosas de la misma orden con la adbocazion de la Madre de Dios».

Margarita TORREMOCHA HERNÁNDEZ

Facultad de Filosofía y Letras. Universidad de Valladolid

Correo-e: torrem@fyl.uva.es

Fecha de recepción: 15 de octubre de 2019

Fecha de aceptación: 20 noviembre de 2019

RESUMEN: La historia de la fundación de conventos es generalmente la relación de numerosos factores religiosos, sociales, económicos, familiares, y por supuesto una parte más de la Historia de la Iglesia. El origen del desaparecido Convento de monjas dominicas de la Madre de Dios que se funda en Valladolid en 1550 es un claro ejemplo. Los intereses de los patronos, los de la Orden, y los avatares posteriores dieron lugar a un monasterio con características propias, pero no exactamente las que se habían proyectado.

* El presente trabajo se ha realizado en el marco del Proyecto «Justicia, mujer y sociedad: de la Edad Moderna a la Contemporaneidad. Castilla, Portugal e Italia», con referencia HAR2016-76662-R de Proyectos de I+D+I, correspondientes al Programa Estatal de Investigación, Desarrollo e Innovación orientada a los Retos de la Sociedad, en el marco del Plan Estatal de Investigación Científica y Técnica y de Innovación 2013-2016 (AEI/FEDER, UE). 


\section{MARGARITA TORREMOCHA HERNÁNDEZ \\ LA “COMPLICADA" HISTORIA DE UNA FUNDACIÓN. \\ DOMINICAS DE LA MADRE DE DIOS DE VALLADOLID (1550)}

La causa de las diversas complicaciones que surgen en la etapa fundacional estuvo muy relacionada con la temprana muerte de su fundador, puesto que sus problemas como mercader y arrendador, y sus deudas, arrastraron al convento. Pero también el que sus hijas actuaran en contra a lo por él propuesto, envolviendo al cenobio en no pocos conflictos en su primera etapa, que desdibujaron el proyecto inicial y condicionaron su vida futura.

Palabras clave: Historia de la Iglesia; Edad Moderna; conventos femeninos; Orden de Santo Domingo; patronatos.

ABSTRACT: Founding of convents history is generally the relationship between numerous religious, social, economic and family causes and, of course, an additional part of the Church's history. The origin of the disappeared convent of Dominican nuns of «la Madre de Dios», which was founded in Valladolid in 1550, is a clear example. The interests of the board, of the Order, and the later transformations gave rise a monastery with its own characteristics, but not the ones wich had been planned. The reason of the diverse complications which arise in the foundational period was related with his founder early dead because his difficulties as a merchant and lessor and his debts had an effect on the convent. But also because his daughters acted against what he proposed, involving the monastery in lots of conflicts during its first period, conflicts which changed the initial proyect and determined its future life.

Keywords: History of the Church; Modern Age; female convents; Order of Santo Domingo; patronages.

En la levítica villa de Valladolid, la orden dominica contó con una presencia significativa, que tenía su núcleo por su protagonismo religioso y político en el convento de San Pablo. De hecho, aunque de manera general se considera que la reforma se había iniciado en Italia, durante el generalato de Raimundo de Capua (1380-1399), bajo la inspiración de Catalina de Siena (Aníz, 1998: 20), para el espacio del reino de Castilla se comenzó hacia 1461 con la reforma del convento de San Pablo de Valladolid, bajo la protección del cardenal Juan de Torquemada (Nieva, 2007: 167).

Este convento desde finales del siglo XV se vio fortalecido con la fundación en un espacio muy cercano - que el mismo cede- del Colegio de San Gregorio (Arriaga, 1928), en el que los miembros de la orden se formarían en Artes y Teología, y al que también acudían a oír sus lecciones otros muchos de los matriculados en las aulas de la Universidad de Valladolid (Torremocha, 1991). 


\section{MARGARITA TORREMOCHA HERNÁNDEZ \\ LA “COMPLICADA" HISTORIA DE UNA FUNDACIÓN. \\ DOMINICAS DE LA MADRE DE DIOS DE VALLADOLID (1550)}

Pero además, en la villa, la rama femenina de la orden tenía también presencia y creció a mediados del siglo XVI. Una de sus fundaciones fue la del convento vallisoletano de la Madre de Dios, de la orden dominica, erigido en 1550, que llegaba a la urbe tras el de Catalina de Sena, de 1488 de la mano de Dña. María Manrique y D. Manuel de Benavides, señor de la Mota, y el de Corpus Christi de 1545, fundado por Ana Boniseni, situado primero en el barrio de San Lorenzo, posteriormente en la villa de Simancas y luego al otro lado del río. El tercero fue el de la Madre de Dios, también de patronato, como lo fueron en la primera mitad del siglo el $91 \%$ de los cenobios (Graña: 2012: 45). Así, de los 35 conventos de mujeres que tuvo la diócesis de Valladolid, 9 eran de dominicas, siendo la segunda orden más representada, tras las franciscanas que contaban con 10 (Barrio, 2016: 188).

La ciudad del Pisuerga es por tanto un ejemplo más de la realidad generalizada, estudiada por A. Atienza, sobre la fundación de conventos femeninos en la segunda mitad del siglo XVI, que se tornó en un fenómeno extendido y cuantitativamente significativo (Atienza, 2013: 19-24). De esa manera eran ya tres los cenobios dominicanos de mujeres, a pesar de que como ha escrito M. Barrio para Valladolid, se fundan menos conventos de monjas que de frailes, porque requieren una dotación inicial más elevada y estable (Barrio, 2016: 188). Conventos que en este caso se tendrán que adaptar a lo establecido en el Concilio de Trento, siendo el de la Madre de Dios el que aparece casi cuando este va a concluir y por tanto no tuvo apenas que acomodarse a un patrón diferente (Soriano, 2000: 479-494).

A pesar de que hoy no se discute la data de su fundación, asumida en 1550 como se reitera en la documentación del claustro ${ }^{2}$, la historiografía aventuró en ocasiones fechas más tempranas sobre este convento, considerando que Doña Inés, hija de Fernando de Gatos, casada con el hijo y sucesor del conde Pedro Niño, podía haber puesto los primeros pilares para que este patronato iniciase su andadura. En su testamento dejó a su hermana Leonor su considerable herencia, con la condición de que instituyese un convento en el marco de la orden de Santo Domingo, y con el título de Madre de Dios, a lo que se sumaban otras mandas piadosas repartidas en misas y obras pías. Sin embargo, este rastro se pierde y, el hecho de que fuera enterrada en la Iglesia de San Martín de la villa del Pisuerga y no en el convento, en cuya documentación no es mencionada en ningún caso, hace descartar tales orígenes (Antolínez de Burgos, 1987: 354; Atienza, 2012: 89-114).

2. Sus fondos documentales no se encuentran completos, pero los que se pueden consultar pasaron al convento de Porta Caeli de Valladolid, conocido como de las Calderonas, por ser una fundación de Don Rodrigo. Archivo del Convento Dominico de Porta Caeli (APC). El resto en el Archivo Histórico Nacional (AHN), Clero-Secular-Regular, Leg. 7840 y Libros 17218/17225 (años: 1663-1837). 


\section{MARGARITA TORREMOCHA HERNÁNDEZ \\ LA “COMPLICADA" HISTORIA DE UNA FUNDACIÓN. \\ DOMINICAS DE LA MADRE DE DIOS DE VALLADOLID (1550)}

La fecha que por unanimidad es aceptada es la de mediados del siglo XVI (Sangrador, 1851-1854: 326-327), que se ha repetido por cronistas de la ciudad (Fernández, 1998) y de la orden de Santo Domingo. El padre M. Hoyos dice:

«El año de 1550, Pedro González de León y su esposa María Coronel, matrimonio distinguido y pudiente, de mucha piedad y afecto a nuestra Orden fundó un Convento de Dominicas, extramuros de Valladolid y cerca de Chancillería, con la advocación de Madre de Dios» (Hoyos, 1968: 105-106).

\section{PATRONOS}

De tal manera que a los patronos les define en cuatro rasgos, los dos primeros relativos a su condición socioeconómica (González, 1893: 601-602) y los dos últimos sobre su religiosidad y vinculación sentimental a los dominicos (Atienza, 2009: 37-54; 2016: 109-134).

Por nuestra parte, los datos que conocemos de Pedro González de León no son numerosos pero sí significativos ${ }^{3}$. Era un mercader y arrendador, de orígenes judíos, vecino de Valladolid cuando acomete la fundación. Antes de serlo, hay constancia de que tuvo una acusación ante el tribunal de la Inquisición de Cuenca, en 1526. El proceso que se siguió contra él no fue por hacer proselitismo, ni por mantener prácticas de la fe de judaica, sino por ofender directamente al Santo Oficio. Su causa estuvo motivada por un comentario que hizo en público, cuando se le dice vecino de Sigüenza. El suceso se remonta a mediados del año 1526, es decir, casi un cuarto de siglo antes. Los testigos - entre ellos su propio confesor - relatan una conversación que Pedro tuvo con otro vecino de la localidad llamado Alonso Preciado, amigo suyo.

«...este testigo [su confesor, Br. Torralba] entendía con el dicho Pedro Gonçalez que fuese amygo / del dicho Preçiado y entre otras palabras que hablaron/ vinyeron a hablar en las cosas de la Ynquisición, este testigo vido / e oyó como el dicho Pedro Gonçalez dixo yo no creo que ay / herejes o hereje, lo uno o lo otro, y este testigo le replicó y dixo / pues sy no ay herejes como que uno y otros se re/ conçilian y confiesan herejías. Y el dicho / Pedro Gonçalez dixo por malos o falsos testigos, lo uno / o lo otro, y los que se reconçilian son unos malaven / turados o desventurados, lo uno o lo otro y este testigo / le dixo no digays tal por amor de dios, y el dicho / Pedro Gonçalez dixo que se lo desya en confesion y que no se/ confesava astualmente con este testigo ny fue entonçes en ju / bileo dado por el emperador

3. Hombre de negocios. En 1495 figura un personaje homónimo que pudiera ser él, como residente en Sigüenza. Archivo General de Simancas (AGS), Registro del Sello de Corte. 149502, legajo 464, fecha 23 febrero de 1495. Un año después, ya en 1496, era administrador de las salinas de Atienza. AGS, Patronato Real 834-1851. 


\section{MARGARITA TORREMOCHA HERNÁNDEZ \\ LA “COMPLICADA" HISTORIA DE UNA FUNDACIÓN. \\ DOMINICAS DE LA MADRE DE DIOS DE VALLADOLID (1550)}

aunque el dicho Pedro Gonçalez / se a confesado dos veses con este testigo y que desde a çiertos / dias este testigo dixo al dicho Pedro Gonçalez y le aconsejó/ que lo dixese ante los señores Ynquisidores, y despues el dicho/ Pedro Gonçalez dixo a este testigo que lo avía dicho e que estavan/ solos e no lo dize por odio,...» ${ }^{4}$

La condena - para la razón y la fecha - fue leve: asistir a la novena de Nuestra Señora de los Huertos, en cuya ermita cada día hiciera decir una misa por las ánimas del purgatorio, pagando por cada una de ellas al clérigo que las celebrara medio real. Y otro medio debía dar cada uno de esos nueve días de limosna para la ermita. Limosna pues que era muy escasa y que Pedro González bien podía dar con generosidad, de lo que le sobraba. Además se le tasaron las costas en 10 ducados. Para saber si cumplía su sanción se dejaba encargado a su confesor. El mero hecho de que existiese un clérigo que se consideraba tal, aunque en los pormenores no parece que se sirviera mucho de él para la práctica sacramental, indica que mantenía las fórmulas de religiosidad habituales y que incluso se acercaba a lo que podíamos denominar asistencia espiritual personal.

El que su confesor le respalde parece tener efecto en el Tribunal:

«le tiene / por tal onbre que (dice?) la verdad y que si en algo su confesión / difiriere de lo que el dicho bachiller dixere que fue por ynalver / tençia y no por maliçia ni por yncobrir cosa de la verdad».

Culminó su sentencia con un apercibimiento legal, declarando que de no cumplir con estas penas tendría pena de excomunión y cien mil maravedíes ${ }^{5}$.

Pero el pasado judío y el paso por el tribunal inquisitorial parece que se borraron o al menos no estuvieron presentes en su estancia como vecino de Valladolid. Los fundadores eran un matrimonio piadoso, de devociones y, en cualquier caso, siempre patronos necesarios, pues las inseguridades de estas comunidades de mujeres hacen preciso contar con el respaldo de «alguna persona o institución que la promueve, apoya o financia, ya sea miembro de la realeza o de la nobleza, de la oligarquía urbana, del clero o el municipio» (Barrio, 2016: 188).

Fue hombre de negocios, cuñado del mercader Juan de Salvatierra ${ }^{6}$, arrendador de las minas de Almadén (adjudicadas entre 1551-54) y de las salinas de Atienza 7 .

4. Archivo Diocesano de Cuenca, Sección Inquisición, Legajo 758, expediente 557, 1526. Transcripción en https://www.histgueb.net/vvictoria/tropiezo.htm. (consultado 18 de abril de 2019)

5. Ibíd.

6. Una de cuyas hijas es la primera que se registra como profesa. Archivo de Porta Coeli (APC), convento de religiosas dominicas de Valladolid. Libro de las profesiones y fenecimientos del convento de la madre de dios desta ciudad de Valladolid, de la orden de nuestro Padre Santo Domingo. Y de las religiosas que mueren en él.

7. Al menos desde 1496. AGS, Patronato Real, 834-1851. 


\section{MARGARITA TORREMOCHA HERNÁNDEZ \\ LA “COMPLICADA" HISTORIA DE UNA FUNDACIÓN. \\ DOMINICAS DE LA MADRE DE DIOS DE VALLADOLID (1550)}

Sus operaciones con destacados hombres empresarios y financieros, como los Fúcares, se reflejan en un corolario de pleitos civiles en los que se vio involucrado por el desempeño de sus actividades. Así, en la documentación fundacional se les atribuye la condición de pudientes y acaudalados, y dichos calificativos que parecen ajustados para los León-Coronel, han sido puesto en algunos casos por la historiografía reciente en duda, como en los estudios publicados por Matilla Tascón, que opta por presentar a la cabeza de esta familia más como un hombre de paja en los negocios que lleva a cabo con los Fúcares (Sánchez, 1989, 306). En cualquier caso, y sin poder conocer con detalle sus actividades y fortuna, datos como que sus ingresos le permitieron convertirse en señor de las villas de Padilla y el Villar y que fundó un mayorazgo nos hacen pensar en una economía fuerte. Al menos eso es lo que se deja percibir en el Libro Becerro, hecho por el dominico Vicente Velázquez de Figueroa (Martín, 1982), en el que se reitera la idea de familia con posibilidades económicas y deseos de seguir un modelo fundacional de tipo nobiliario, que además les era conveniente - en principio - por tener tres hijas:

«...haviendo fundado un Maiorazgo para sus hijos y de mas sus subzesores: hallándose con algunos vienes que dios nuestro Señor les dio, y queriendo los emplear en servicio de su magestad movidos de la afizion y devozion que tenían a la Orden de nro. Padre Santo Domingo determinaron fundar un convento de Religiosas de la misma orden con la adbocazion de la Madre de Dios en unas casas que dichos señores tenían detrás de la Iglesia de San Pedro de Valladolid,...» ${ }^{8}$.

Se casó con doña María de León Coronel con la que promueve la fundación, y ambos pasaron a residir en Valladolid, donde ya vivían años antes de iniciar su labor de patronos. Tuvieron tres hijas (todas ellas arrinconaron el apellido González) llamadas doña María, doña Mencía de León, doña Ana León o Coronel, en las que sin duda pensaron a la hora de tomar su decisión fundacional.

Por tanto, los patronos acometieron su empresa después de fundar en 1541 un mayorazgo, que en principio recayó en su hija Mencía de León, casada con Álvaro de Luna'. La vinculación de sus bienes hizo que a su muerte tanto sus hijas como

8. AHN, Secc. Clero Regular-secular, libro 17222, Libro Bezerro de el convento de la Madre de Dios de la ciudad de Valladolid, compuesto por el Padre Fray Vicente Belazquez, hijo del combento de San Pablo: hizose siendo Priora la Madre Doña Micaela Albar, y depositaria Soror Spha de Agüero y Sororo Magdalena Junco, año de 1769.

9. En una ejecutoria se conserva parte del testamento de Mencía de León en el que nombra a su marido heredero universal, Archivo de la Real Chancillería de Valladolid (ARCHV), Ejecutoria del pleito litigado por Ana de León, mujer de Álvaro de Luna, vecinos de Valladolid, con Gaspar de Anuncibay, vecino de Valladolid, sobre ejecución en bienes de Gaspar de Anuncibay para hacer pago a Álvaro de Luna de cierta cantidad de ducados que restaban de réditos del 


\section{MARGARITA TORREMOCHA HERNÁNDEZ \\ LA “COMPLICADA” HISTORIA DE UNA FUNDACIÓN. \\ DOMINICAS DE LA MADRE DE DIOS DE VALLADOLID (1550)}

las monjas del convento se vieran con dificultades para conseguir las cantidades ofrecidas a unas como a otras.

Para la ubicación del monasterio pensaron en un espacio muy cercano a las casas que entonces ellos ocupaban en Valladolid. Los González León y Coronel vivían entonces en la calle Real de Burgos, junto a la parroquia de San Pedro Apóstol. A partir de 1559, muertos los progenitores las hijas se marcharon, dejando ese espacio en alquiler para las cárceles y el tribunal de la Inquisición, que tuvo allí su tercer y más importante emplazamiento vallisoletano (Antolínez, 1887: 179).

De hecho en sus cuartos se estableció el Tribunal nada menos que durante trece años, pero sin cambiar de propiedad que seguía siendo de «los León». Fue posteriormente cuando sus sucesoras hicieron la venta a la Inquisición - tras la consiguiente y necesaria autorización del monarca Felipe II - , siendo la encargada entonces de hacer la transacción su hija y heredera doña Mencía Coronel y su esposo (Fernández, 1990: 191-201).

Doña María murió poco después de la fundación y él, el 3 de noviembre de 1558 en la casa real que estaba junto al Monasterio del Abrojo, próximo al lugar de La Laguna (actual Laguna de Duero, Valladolid) ${ }^{10}$. En sus últimas voluntades al testar aparece una de las claras y comunes intenciones de su fundación: que el convento sirva de sepultura. Así, declaraba que quería que ambos debieran ser enterrados en la Iglesia del Monasterio cuando estuviera acabada.

\section{CONVENTO DE LA ORDEN DE SANTO DOMINGO}

Estas referencias que conocemos sobre el momento fundacional, los patronos, su entorno personal y familiar son solo una parte de las coordenadas de esta fundación, pues, el convento que ellos ponían en pie, y dotaban no estaba completo sin la vinculación a una Orden religiosa a la que se acogerían sus moradoras, cuya regla seguirían y, en consecuencia, se vincularían en lo espiritual pero también en su trayectoria secular.

Cuando el patrón establece esta concordia con la Orden, su derecho de patronato se ve limitado y en consecuencia sus intromisiones en la institución religiosa «distinguiendo entre el antiguo derecho de propiedad fundado en la titularidad del suelo y el deber de protección a las mismas» (Graña: 2012: 45).

censo impuesto sobre la granja del Villar, ARCHV, Registro de Ejecutorias, Caja 1690,42 - 2. 27 de abril 1591.

10. Otorgó testamento ante el escribano de dicho lugar Antonio de Morales. AGS, Expedientes de Hacienda, leg. 537, pieza cuarta. Borrador del testamento de Pedro González de León, vecino de Valladolid, señor de las villas de Padilla y El Villar. AGS, Cámara de Castilla, DIV, 37, 33, sin fecha. 


\section{MARGARITA TORREMOCHA HERNÁNDEZ \\ LA “COMPLICADA" HISTORIA DE UNA FUNDACIÓN. \\ DOMINICAS DE LA MADRE DE DIOS DE VALLADOLID (1550)}

Por ello, cuando seguimos las fuentes de la orden dominica, a sus cronistas no les interesan las figuras de los patronos más allá de sus buenas intenciones y sus posibilidades para respaldar económicamente la empresa. Ponen su mirada sobre todo, en que esa misión se lleva a cabo por la aceptación de esa fundación particular por parte de la Orden y, cómo y de manos de quién se produjo. De hecho, este dato se recoge reiteradamente también en otros documentos conservados del cenobio. En el libro en el que se toma nota de las profesiones de las religiosas que entran en el convento se hace una introducción en la que se registra:

«Año de mill y quinientos y cinquenta recivio la orden a su gobierno el convento de la madre de dios de esta ciudad, siendo maestro general de la orden el reverendísimo padre fray Serafino Cavalli, y provincial de la provincia de Hespaña, el muy reverendo padre maestro fray Bartholome de Miranda y prior del convento de San Pablo de Balladolid fray Juan de Valcaçar, fundaron el dicho convento y dotaronle los illustres señores don Pedro Gonçalez de León y doña María coronel su muger» ${ }^{11}$.

Por tanto, se da prioridad a lo concerniente a la solicitud que se hace al capítulo de la orden de Santo Domingo para que tome su fundación bajo su tutela. Fue, en un cabildo de la Orden, celebrado en Segovia, a cuya cabeza estuvo don Bartolomé de Carranza y Miranda, que había sido electo recientemente (6 de febrero de 1550) en un capítulo celebrado también en Segovia. Los dominicos para dar su aprobación encargaron la elaboración de un informe colegiado del prior del convento de San Pablo y el del colegio de San Gregorio, ambos de la villa de Valladolid, que entonces eran Fray Juan Valcárce y Fray Antonio de Santo Domingo, al que se unió Fray Juan Manuel. Sus opiniones fueron por tanto las que respaldaron la vinculación de esta fundación a los dominicos (Hoyos, 1968).

Así pues la Orden de Santo Domingo quería seguridades que le animara a vincularse a esta empresa y buscaba «...pudiese asentar con los dichos fundadores todos los partidos y condiciones que le pareziesen justos y razionables para la perpetuidad de la dicha Fundazión y de la seguridad que en este caso ha de haver la orden para poder servir la dicha casa y monasterio a gremio de los otros monasterios de la dicha Orden...». La decisión de los presentes sería aceptada por los padres definidores: «para que goze de todas las prerrogativas gracias y privilexios conzedidos por los mismos Pontífizes y por los conzilios generales a la orden de nuestro padre Santo Domingo» ${ }^{12}$.

Finalmente el día 7 del mes de octubre se hicieron las capitulaciones y tomó posesión la Orden del dicho Monasterio (Hoyos, 1968: 326). No obstante, la

11. APC, Libro de las profesiones....

12. Escritura 1 de mayo de 1550, AHN, Secc. Clero Regular-secular, libro 17222, Libro Bezerro..., año de 1769. 


\section{MARGARITA TORREMOCHA HERNÁNDEZ \\ LA “COMPLICADA" HISTORIA DE UNA FUNDACIÓN. \\ DOMINICAS DE LA MADRE DE DIOS DE VALLADOLID (1550)}

dotación correspondía a los patronos. Cuando Pedro y María se comprometen como fundadores lo hacen aportando una renta anual de 800 ducados. Esta cantidad que se ofrece en los comienzos se vio poco después reforzada con la donación que hizo el papa Julio II a este convento, de un beneficio en el lugar de Cienpozuelo del arzobispado de Toledo, que les permitía gozar con 600 ducados de renta anual (Hoyos, 1968: 327), pasando a ser la renta de 1.400 ducados al año. Y, como era habitual en estos conventos, a esa suma se añadiría el resultado de las cantidades dotales con las que ingresaran cada una de las monjas al convento, dado que no era una fundación en la que las profesas estuvieran libres de esta aportación, como ocurrió a principios del siglo XVII con la constitución de dominicas reformadas de la Laura, también en Valladolid que se constituyó con la idea de que sus monjas no tuvieran que aportar dote, algo que posteriormente fue revocado (Aniz, 1998: 130).

\section{EL PROYECTO DEL CONVENTO}

Los planes de Pedro González de León para el convento están reflejados en buena manera en su testamento, en el que por supuesto aborda otras muchas cuestiones, pero el convento tiene un claro protagonismo. En el momento de testar pide que se pague todo lo que a su muerte por escritura se deba, pero con el dinero restante se compromete a costear algunas obras de caridad que deseaba realizar con sus bienes como dejar a Valladolid, en la que había residido, 2.000 fanegas de trigo para ayuda y depósito de la dicha villa para pobres y vender en tiempo de necesidad.

Tiene un recuerdo para otras mujeres desfavorecidas de Valladolid, las que habían abandonado la prostitución y se encontraban amparadas en una casa de las llamadas de arrepentidas. Este recogimiento es denominado en su testamento como convento. Por lo tanto pudo ser el de San Felipe de la Penitencia, situado ya en su segunda ubicación. Hasta 1541 este centro estuvo situado en la calle Francos de la villa, donde las puso Fray Bernardino Minaya o Miranda, un dominico, «cuya fama grande le concilió los mayores aplausos de todos en Valladolid». Y, con posterioridad se instalaron en un espacio «próximo a la puerta que antiguamente llamaban de Teresa Gil, que tiene delante una plazuela muy capaz», y desde sus orígenes fue «la comunidad del convento de San Pablo la que se encargó de asistirlas y confesarlas, mirando por ellas en todo lo espiritual» (López, 1613).

De hecho, tradicionalmente estas mujeres estuvieron atendidas por la Orden de Santo Domingo, pues en Valladolid su número debió ser crecido - a tenor de la elevada población flotante masculina - y pronto se constituyó otra casa fundada por dos mujeres, una de ellas la conocida Magdalena de San Jerónimo, autora de un memorial sobre castigo y reclusión de mujeres perdidas, que redactó por encargo de Felipe III (Torremocha, 2018). Pero esta residencia no pudo ser la beneficiaria puesto que no empieza a funcionar hasta la última década de la centuria y además 


\section{MARGARITA TORREMOCHA HERNÁNDEZ \\ LA “COMPLICADA” HISTORIA DE UNA FUNDACIÓN. \\ DOMINICAS DE LA MADRE DE DIOS DE VALLADOLID (1550)}

no fue convento sino una casa pía de Aprobación. Si bien, la historiografía suele presentar alguna confusión dado que esta casa siempre estuvo regida por monjas dominicas, en concreto cuatro (priora, subpriora, maestra de novicias y portera), que llegaban de otros conventos de la propia localidad o más o menos cercanos, como la ciudad de Toro (Torremocha, 2014).

A ellas o al convento le deja por testamento 400 ducados con la idea de ayudarlas, pero como contraprestación para que recen por su alma. De tal manera, que en sus dos mandas establecidas para ayuda de mujeres, está el pensamiento de asegurar las oraciones necesarias para su salvación y, en ambos casos, hace una opción por la Orden de Santo Domingo. Porque el grueso de las misas que pide para después de su muerte establece que todas ellas se digan en el Monasterio de la Madre de Dios.

\subsection{Espacios, arquitecturas, dependencias}

Los patronos dan al convento un espacio generoso con sus escrituras. La elección de los suelos se hace muy cerca de su casa, extramuros de la ciudad, pero junto a la importante institución del Tribunal de la Chancillería. Se trataba de un solar que iba por la parte trasera de la Iglesia de San Pedro y llegaba hasta el río Esgueva, y por la parte lateral a la calle Real. Estos terrenos no eran de su propiedad, sino que para la edificación compró Pedro González de León «una huerta con su casa y dos norias y un pedazo de majuelo a Diego de Carriazo, vecino de esta villa con la carga de un censo perpetuo a favor de la cofradía de ánimas de la iglesia de San Pedro de 5.000 mrs. y tres pares de gallinas o por ellas seis reales ${ }^{13}$.

No todo el terreno era para cimentar, sino que parte de ello se construiría y «otro gran pedazo de dicho suelo» se pensaba que podía y debía ser para una huerta que se quería mayor que la que se había comprado. La gran parcela, estaría «cercada al dicho monasterio", pues el fin era «aprovecharse de ello el dicho monasterio como quisiere, y por bien toviere» ${ }^{14}$.

Se optaba así por garantizar a las religiosas una fuente para asegurar su sustento directo a través de lo que en la granja se recolectase e incluso si era mucho, lo que se ganara por su venta. Pero esto suponía por una parte la exigencia de un trabajo manual para alguna de las monjas, al que la mayoría no estarían acostumbradas, ni tampoco dispuestas a desempeñar. Las labores y más de este tipo se entiende que eran solo para las legas, que siempre fueron una minoría en él (Torremocha, 2019). Por otra esta opción representaba la obligación de tener abierto el convento para las ventas del producto. Y, ambas circunstancias podían ser difíciles de conciliar con la vida conventual de las dominicas y con su regla, como quizás se demostró a la postre.

13. Ibíd., p. 45.

14. Ibíd. 


\section{MARGARITA TORREMOCHA HERNÁNDEZ \\ LA “COMPLICADA” HISTORIA DE UNA FUNDACIÓN. \\ DOMINICAS DE LA MADRE DE DIOS DE VALLADOLID (1550)}

De hecho, unos años más tarde, la duquesa de Alba en su fundación dominica de la Laura era tajante al respecto: «jamás tengan en ese monasterio bienes raíces, ni mucho menos granjerías, ni siembren, ni recojan pan, vino ni aceite», aunque fuese para el culto divino (Aniz, 1998: 132).

Estas huertas y su aprovechamiento fueron las causantes del primer conflicto que se generó desde el convento como comunidad que al parecer también lo fue de productoras. En el mismo año de la fundación tuvo que pleitear con el Abad y cabildo de Santa María la Mayor ante la real Chancillería sobre si debía o no pagar este monasterio el diezmo de lo que produjese. Las dominicas perdieron el pleito y, como consecuencia, se vieron obligados el convento, sus mayordomos y las monjas

«...a pagar enteramente al prior y cabildo de dicha iglesia mayor de Valladolid de todo lo que coxeren y labraren en sus heredades que al presente tienen y tobieren de aquí adelante adquiridas por cualquier título o razón aunque sea dote del dicho monasterio de monjas e freila o herencia ansi de lo que labraren por sus criados ... $\mathrm{y}$ de todos los ganados que tuvieren y criaren con que se entienda que las huertas que tuvieren cercadas con su monesterio para recreación de las dichas abadesa, e priora e monjas y convento de dicho monesterio,...».

Solo se verían libres de pagar por lo que criaren dentro del monasterio, y el Abad de la Colegiata de Valladolid tenía todo el derecho a cobrar

«...diezmo del monton y heras donde estuviere por su propia autoridad sin denunciación alguna, no obstante cualquier previlegio concedido o que se concediere por nuestro muy santo padre e por otra persona alguna que poder para ello tenga por cualquier via...» ${ }^{15}$.

En definitiva, la extensión de la huerta debía de ser suficiente para que el cabildo se molestara en reclamar sus derechos. Aunque el texto nos permite conocer también que se labra con el trabajo de criados.

Por lo demás, tan amplio suelo quedaba desde el principio sujeto a posibles modificaciones, pues esta parte no edificada en algún momento podría llegar a transformarse, pensando en hacer en ella casas para los patronos o en destinarse para que estos incrementasen su mayorazgo. Esta contingencia se dejaba abierta, pero no sin condiciones, entendiendo que de hacerse sería siempre con total respeto al convento y a su clausura, que debía ser la razón prioritaria en cualquier actuación.

15. ARCHV, Ejecutoria del pleito litigado por la catedral de Valladolid, con Pedro González de León y el convento de la Madre de Dios, orden de Santo Domingo, de Valladolid, sobre el perjuicio que la construcción de éste, supone para la iglesia de Santa María la Mayor, de Valladolid. Registro de Ejecutorias, Caja 819,17, 1554. 


\section{MARGARITA TORREMOCHA HERNÁNDEZ \\ LA “COMPLICADA" HISTORIA DE UNA FUNDACIÓN. \\ DOMINICAS DE LA MADRE DE DIOS DE VALLADOLID (1550)}

« si lo tal acaeciese los que tomasen los dichos suelos podría ser que alzasen tanto las casa y hedificios que labrasen que descubriesen el dicho Monasterio o la Huerta o parte de ello, y por que esto no combiene a la onestidad e clausura de el dicho Monasterio se asienta que si en algún tiempo en la dicha Huerta se hoviese de edificar haia de ser con condizion que en las casas e otros edifizios que se hizieren no se puedan hazer ni agan vistas ni ventanas que sojuzguen el dicho Monasterio ni parte alguna de el, ni de la dicha Huerta,...».

En el resto de este espacio, lo que hoy sabemos de la construcción del monasterio desaparecido se debe a lo concertado entre patronos y orden de Santo Domingo, en la reunión de incorporación mantenida en Segovia, donde Pedro y María dejaron firmado a todo lo que se comprometían, después de haber comprado y cedido el terreno. De tal manera que conocemos, lo que se planeó y en buena medida se edificaría, como una foto fija, puesto que no hay relación posterior de esas zonas, salvo algunas muy parciales que se pueden llegar a considerar a través de gastos de arreglos y adecentamiento posteriores.

No obstante, el cuidado y pormenor con que se hizo la escritura nos permite una reconstrucción en cierta medida completa, al menos para acabar en parte con el total desconocimiento de este desaparecido convento vallisoletano. Las diferentes piezas que se planean reflejan las altas miras de los fundadores para el monasterio en el que no quisieron olvidar ninguna dependencia para el buen desarrollo de la vida monástica.

Iglesia y coro fueron los primeros trabajos que se acometieron. De hecho ya se habían empezado cuando se hace la escritura, habiéndose puesto todos los cimientos de la capilla mayor para entonces. Se concibió con un crucero, cuerpo central de bóveda, y el coro artesonado en su techo, de 75 pies de largo por 35 de ancho (Piñeiro, 2000). De todo ello solo quedan los elogios a la construcción con afirmaciones tales como «primitivo templo con resabios de gótico» o la de Antolínez de Burgos: «Iglesia y convento es fábrica de gran importancia».

Los datos que tenemos sobre la iglesia están todos preferentemente vinculados a su sepulcro, lo que es representativo del objeto de su interés. Todo indica que desde el principio se preocuparon de sus enterramientos en la iglesia como elemento determinante.

«Ytem que la capilla maior de la Yglesia de el dicho Monasterio el Cruzero de ella todo de la Reja adentro que esta comenzada a edificar e se ha de acavar por la orden que esta dicha haia de ser y sea perpetuamente para asiento y enterramiento de los dichos fundadores e de sus subzesores y descendientes puedan hazer y poner bultos y tumbas en los harcos de la dicha capilla maior e poner piedras llanas en el cuerpo de ella con solo letrero y armas...» ${ }^{16}$.

16. AHN, Secc. Clero Regular-secular, libro 17222, Libro Bezerro..., año de 1769. 


\section{MARGARITA TORREMOCHA HERNÁNDEZ \\ LA “COMPLICADA" HISTORIA DE UNA FUNDACIÓN. \\ DOMINICAS DE LA MADRE DE DIOS DE VALLADOLID (1550)}

No se tienen más pormenores de la iglesia, salvo que en ella fueron enterrados sus fundadores, en unos sepulcros de alabastro (un bulto y una cama) realizados por Inocencio Berruguete, sobrino del escultor Alonso, que si no desaparecieron con el convento se desconoce dónde fueron a parar. El 17 de diciembre de 1550 acordaron el escultor con Pedro González de León que hiciese los bultos sepulcrales de su mujer y el suyo. En la escritura se convino que hasta el día de la entrega se le darían 60 ducados «pagados por sus tercios». Y, posteriormente, a obra acabada «como dicho es a contento del Sr. Pero González e a avista de oficiales» daría el resto pues se consideró que era mejor una valoración final, según lo que ordenara por tasación su tío, el ya afamando Alonso Berruguete, «tan perito en su arte». Como María Coronel ya había muerto (Agapito y Revilla, 1937/2004: 255) había prisa para tener el enterramiento terminado y por lo que se dice en la escritura se exige premura, pues Inocencio «se obliga de no alçar la mano de la dicha obra hasta darla acabada para el dicho día de Santiago [1551] e asentada en toda perfeçion».

Después, finalizado el trabajo González no se quiso acomodar a la tasación del artista sino dar una cantidad menor, lo que motivó un pleito en el que intervinieron distintos testigos, presentados en probanza por cada una de las partes ${ }^{17}$. Según las opiniones de los comparecidos por Don Pedro, que respaldaban su opinión, se había producido un comportamiento poco profesional del artista: «Inocencio no empleó más que unos pocos aprendices a los que no les daba cosa alguna syno de comer tan solamente, y aun ellos le dan dinero y le sirven de gracia porque les muestre Berruguete su tío el oficio» (Martí y Monsó, 1898-1901: 177; Alonso et allí, 2018: 136). La Chancillería le condenó a pagar una cantidad muy superior a la que ya había abonado y el proceso se prolongó años, con apelaciones.

En principio optaron por reservarse todo el espacio de la Iglesia para este fin impidiendo otros enterramientos (Graña, 2012: 46). Saltarse la prohibición de que en esa capilla se enterrase cualquier otra persona supondría perder la dotación al convento destinándose la mitad para el Hospital de la Madre de Dios, «...que hacen los dichos fundadores junto al dicho Monasterio», y la otra "para el subzesor en la dicha su Casa e Mayorazgo para que lo gasten y destribuian en casar huérfanas». No se admitía disposición en contrario pues entonces el Monasterio desaprovecharía «la dotazion que hagora se le haze e si les fuere dada de propio motuo la tal disposizion no usaran de ella so la dicha Pena».

No obstante, a pesar de esta cláusula sí se produjeron modificaciones, y no parece que tuvieran tales consecuencias. De hecho, otros encontraron allí su descanso y al estar la iglesia del convento en el marco de la parroquia de San Pedro, prácticamente

17. ARCHV, Pleito litigado por Inocencio Berruguete, artista, con Pedro González de León, vecinos de Valladolid, sobre incumplimiento del contrato por el que éste encargó la realización en alabastro de su sepultura y la de su mujer, María Coronel, en el monasterio de la Madre de Dios, y se comprometió a pagar lo que tasara Alonso Berruguete, Pleitos Civiles, Quevedo (Fenecidos), Caja 891,1.1551-1554. 
MARGARITA TORREMOCHA HERNÁNDEZ

LA “COMPLICADA” HISTORIA DE UNA FUNDACIÓN.

DOMINICAS DE LA MADRE DE DIOS DE VALLADOLID (1550)

lindando con ella, el patrono tuvo que otorgar una escritura en favor de esta y cambiar su decisión («por la que se obligó, y a sus bienes, y suzesores de que no se enterraría persona alguna en la Yglesia de este comvento, y si se sepultase se la daría a la dicha Yglesia de sus vienes por cada un año 2.000 mrs. de ofrendas») para admitir a otras personas seglares «que tuviesen debozion de enterrarse en dicha Yglesia». Se abría así el camino para que se produjese si las solicitudes llegaban en el futuro y, dejaba la resolución a la elección de la priora y religiosas:

«...quedando a cargo de este combento de pagar a la dicha Yglesia de San Pedro los sobre dichos $2.000 \mathrm{mrs}$ de los vienes del tal difunto quedando libre de esta obligazion la dicha doña Mencia, y sus herederos, y con estas condiziones hambas partes se apartaron de todos los Pleitos movidos y por mover, que entre ellos ha avido, y que para la maior firmeza de esta escriptura se sacase a costa de este combento confirmazion de ella de su Santidad» ${ }^{18}$.

Y, según ya dejó recogido García-Valladolid (González, 1893: 200), esto se produjo entrado el siglo siguiente y no fueron los fundadores los únicos que eligieron el convento para tomar tierra, pues el doctor Pedro Balmaseda y Vivanco, médico de Valladolid, y su mujer Doña María Canseco - hermana de la más célebre Catalina Canseco (Torremocha, 2003: 127-132) - se enterraron allí, y sobre sus sepulcros pusieron sus escudos de armas $^{19}$.

Los testamentos de ambos así lo confirman:

«Valladolid, 28 de enero de 1627 [...] el doctor pedro de vivanco balmaseda medico vezino desta ziudad de valladolid estando enfermo [...] mi cuerpo sea enterrado en la iglesia del monesterio de la madre de dios desta ciudad en la parte que pareciere a la señora priora y a las demas señoras monjas de el consejo del dicho monasterio y a mis hijas que en el estan por monjas y se pague lo que sus mercedes fueren serbidas acordandose de los muchos años que yo las he serbido y curadolas. yten que mi cuerpo sea llebado ocultamente al dicho monasterio y alli se ponga en un ataud y se agan obsequias...»

«Valladolid, 25 de junio de 1637 [...] yo doña maria de vitoria y canseco vezina desta çiudad de valladolid biuda del doctor pedro de balmaseda y vivanco medico difunto vezino que fue della estando sana [...] [...] mi cuerpo sea enterrado en el monasterio de la madre de dios de esta çiudad en la sepultura donde estan enterrados

18. AHN, Secc. Clero Regular-secular, libro 17222, Libro Bezerro..., año de 1769.

19. Aunque no se pueda confirmar con exactitud entre ellos pudo haber un vínculo familiar, como se puede apreciar por la Ejecutoria del pleito litigado por Ana de Canseco, viuda de Pedro de Carrión, vecina de Valladolid, con el licenciado Lorenzo Pérez, abogado en Coria (Cáceres), sobre pago a Ana de Canseco y a los demas herederos que quedaron de el licenciado Jerónimo de León, hermano de Ana de Canseco, cierta cantidad de maravedís que restan del precio en que se vendieron los bienes que quedaron del dicho licenciado, ARCHV, Registro de Ejecutorias, Caja 1549,33 1586. 


\section{MARGARITA TORREMOCHA HERNÁNDEZ \\ LA “COMPLICADA" HISTORIA DE UNA FUNDACIÓN. \\ DOMINICAS DE LA MADRE DE DIOS DE VALLADOLID (1550)}

los dichos doctor balmaseda mi marido y don pedro de balmaseda mi hijo la qual con el altar que esta junto a ella es propia nuestra $[\ldots]{ }^{20}$.

Salvo las cuestiones relativas al enclave y estética de los sepulcros, ningún detalle más conocemos de la Iglesia que, según el dibujo que nos dejó Ventura Seco en el siglo XVIII, tenía fijado a ella el convento, cuyas estancias estaban alrededor del claustro. En concreto junto al altar mayor, estaría pegada la sacristía pequeña necesaria para que los clérigos y capellanes se revistieran antes de la liturgia. Al ser la de uso cotidiano, se planificó como era costumbre con unos cajones para guardar los ornamentos y todos los utensilios precisos. Luego se haría otra sacristía denominada Mayor, también recubierta de arcas y cajones, en la que se colocarían los instrumentos más valiosos que se utilizarían en ocasiones destacadas: «las cruzes e calizes e plata e ornamentos ricos de el dicho Monasterio». En esta se acumularían los objetos de valor a los que tanta importancia dio el patrón

«...porque la voluntad e intención de los dichos Fundadores es que siempre haia en el dicho Monasterio ornamentos Ricos y se conserven los que agora ai que cada subzesor en el dicho Maiorazgo dentro de un año que comenzara ha eredar haia de dar y de 100 ducados para comprar ornamentos los quales se les compren a su boluntad y en ellos se pongan tan solamente las armas de los dichos señores fundadores e que si no dieren dentro de el dicho año los dichos 100 ducados o no comprare los dichos ornamentos que la priora los pueda mandar cobrar de el por la orden que para ello comvenga porque esta es la yntenzion de los dichos señores fundadores y con esta condizion harán el dicho su Maiorazgo» ${ }^{21}$.

Unos objetos por los que se identificase al convento y que no saliesen a poder ser de él, salvo en ocasiones muy razonadas, pero no de las manos de la orden dominica.

«Ytem que los ornamentos e la plata e tapizeria que hoviere en el dicho Monasterio hagora y para siempre jamas no se pueda prestar ni preste por ninguna causa $\mathrm{e}$ Razon que sea a salvo algún dia de gran necesidad que en tal caso se puedan prestar con lizencia de el Provincial que a la sazón fuere firmada de su mano y esto sea para un dia e no mas para el Monasterio de San Pablo o para e Monasterio de Santa Cathalina de Sena de esta villa y no para otra ninguna parte» ${ }^{22}$.

Sin embargo, aunque fueran diferentes y acumulasen piezas distintas, a ambas sacristías se accedería por un mismo sistema: «e de la una Sachristia a la otra ha de haver un torno por el qual se pidan e den los ornamentos y otras cosas que para el servizio de la iglesia sean necesarias». Además, se añadía: «Ytem se ha de hazer un

20. Anastasio Rojo, Real Biblioteca, Investigadores. Consultado el 1 de mayo de 2019 https://investigadoresrb.patrimonionacional.es/node/6766.

21. AHN, Secc. Clero Regular-secular, libro 17222, Libro Bezerro..., año de 1769.

22. Ibíd. 
MARGARITA TORREMOCHA HERNÁNDEZ

LA “COMPLICADA” HISTORIA DE UNA FUNDACIÓN.

DOMINICAS DE LA MADRE DE DIOS DE VALLADOLID (1550)

capitulo junto a la sachristia maior el qual, y las dos sachristias han de estar abrazadas con el cuerpo de la Iglesia».

Para el alojamiento de las monjas pensaron en unas dependencias o dormitorios pues mientras se finalizaba el edificio estaban en lo que denominan casa antigua. El espacio para este fin tendría 200 pies de largo y 33 de ancho, que se cerraría para construir nada menos que 76 celdas. Amplio número pues ya sabemos que nunca tuvo una cifra tan alta de monjas viviendo en él. La ubicación era alta o baja. Las primeras sobre la huerta y las segundas sobre el claustro, pero en ambos casos se pedía «an de quedar acabado en toda perfeccion con su maderamiento plano».

Descansaban las del piso superior sobre un claustro de 80 pies de ancho, con arcadas en las que los pilares serían de piedra y los arcos de ladrillo, y en el techo artesonado de maderamiento llano, con la técnica de cinta y saetino ${ }^{23}$.

Un amplio refectorio para comer, como en todo convento, de las mismas dimensiones que la anchura del claustro, también con artesonado de maderamiento llano, y con la misma técnica.

Y para atender a las que carecieran de salud una dependencia propia, con alcobas y una chimenea para el conjunto de la sala. Para ellas, después de la escritura fundacional, en su testamento, tuvo un recuerdo dejando otra partida para que la priora lo gastase y distribuyera en cosas necesarias a las enfermas y enfermería de dicho monasterio, entendiendo que así se reforzaba la protección a las monjas más necesitadas.

Con chimenea se planearon también las dos casas de labor que se incluyen: una para verano y otra para invierno, si bien no se habla de cuál será la labor. Desde luego no la relacionada a la huerta, sino probablemente otra manual pero vinculada a la aguja y tejido más propia de la actividad femenina, pero como ha señalado $O$. Rey, aun así bastante impropia de los cenobios, al que no acudían las mujeres pagando unas elevadas dotes para trabajar (Rey, 2009: 63). Sus dimensiones serían las mismas que las del dormitorio, marcadas por tanto por el ancho del claustro, y de nuevo se propone el uso de artesonado de madera, especificando en esta ocasión que sea de Soria, y manteniendo la misma técnica para ensamblarlo.

El edificio contaría con dos claustros. Además del citado, que albergaría los espacios más destacados se haría otro en torno al cual habría otras dependencias de menor calidad, como eran la cocina, despensa, paneras, bodega, casa de horno, lavandería y corral de aves, «y todas ofezinas para su servizio de el dicho Monasterio», pero para estas zonas menos nobles la madera se traería de la localidad segoviana de Cuéllar.

23. Técnica de cuajado de maderas mediante el uso de cintas y saetinos. Las cintas en sentido perpendicular a los pares, y los saetinos en paralelo, de manera que se intersecan y cuajan el espacio, permitiendo que las separaciones entre las diferentes tablas no sean visibles. En ocasiones se usaba para evitar que las arcillas y rellenos de la parte superior, en el caso de un artesonado, por ejemplo, no puedan caer al piso inferior. 


\section{MARGARITA TORREMOCHA HERNÁNDEZ \\ LA “COMPLICADA" HISTORIA DE UNA FUNDACIÓN. \\ DOMINICAS DE LA MADRE DE DIOS DE VALLADOLID (1550)}

La clausura tendría su representación visual y protectora a través de una gran cerca que rodearía todo el monasterio y que le aislaría de la población. La muralla recorrería los dos claustros, la iglesia, y el resto de las dependencias, salvo los corrales. Las calidades también buenas y concretamente definidas: «han de hazer y an de llevar su cimiento de cal y canto, y sus tapias con su clavos y azera de cal y ha de ser de siete u ocho tapias de alto y encima sus almenas,...». Incluso los corrales externos se decía «se han de cerrar con sus paredes altas de mui buena tapieria con sus cimientos de cal y canto tan altas las paredes como las que agora tiene la Huerta que está dada al dicho monasterio».

La ocultación necesaria para la vida honesta que se quería que tuvieran las monjas estaba en relación con esas altas tapias y evitando que alguna construcción de vistas o ventanas permitiera observarlas contra la clausura de la que ya se habla, unos años antes de concluir Trento, «e si alguno contra esto fuere por el mismo hecho haia perdido y pierda el sitio que ansi tuviere, y los edifizion (sic) que en el tubiere hechos».

La idea era hacer una obra destacada, contando con artesanos reconocidos y que dieran con su labor un mayor prestigio a la casa. Se quiso edificar con grandeza hasta el punto que se llegó a considerar uno de los mejores que en Castilla tenía la Orden. Los patronos se comprometían por escritura a dárselo a las monjas todo hecho y acabado antes de 1557, es decir siete años después de la fundación y vinculación a los dominicos. Y lo hacían considerando que uno de ellos, o los dos, podían haber muerto antes de esta fecha. Entonces, lo finalizaría su sucesor en la casa y mayorazgo y de no hacerlo no tomaría posesión de él:

«sea obligado ha acavar lo suso dicho en la manera que dicha es e que hasta dar siguridad bastante para que ansi lo pagara y cumplira no pueda tomar ni aprender los vienes de el dicho Maiorazgo y los dichos señores Pedro Gonzáles y su muger lo pongan asi por condizion en la escriprtura de el dicho su maiorazgo».

Aunque ellos se obligaban a dar el edificio terminado, más los ochocientos ducados de renta, sabían que todo espacio construido y habitado necesitaba un continuo mantenimiento al que querían atender desde su origen (Hoyos, 1969). Por ello, en la escritura más específica dijerón:

«por la presente se obligan que demás de los dichos edefizios que como dicho es se han de hazer han de dar y darán en dote al dicho Monasterio trezientas mil mrs. de Renta al quitar a rrazon de quinze mil mrs. el millar que monta en ella doze mill ducados que son quatro cientos y quinientos mil mrs.».

Creían que esos 300.000 podían ser más que suficientes y por tanto lo que sobrare se destinaría a esa tarea. Pero si no era así se quisieron asegurar estableciendo que la dote que trajesen las monjas tendría una parte proporcional (el 33,33\%) a ese fin. 


\section{MARGARITA TORREMOCHA HERNÁNDEZ \\ LA “COMPLICADA" HISTORIA DE UNA FUNDACIÓN. DOMINICAS DE LA MADRE DE DIOS DE VALLADOLID (1550)}

«que los dotes que las tales trajeren se gaste las dos partes de ello en comprar Renta o Hazienda para el dicho Monasterio, y la otra tercera parte se de a los dichos señores fundadores para aiuda de los dichos edificios».

El resultado, por lo anotado en el Monopolitano fue más que satisfactorio: «Edificose la Iglesia y comvento con la grandeza que agora tiene que es de las mayores que tiene monasterio de monjas en Castilla» (Monopolitano, 1613: 309).

\section{2. ¿Hospital y casa de doncellas?}

Además, junto al convento los patronos pensaron en otras dos instituciones, que podían ser similares, de gran envergadura o de pequeña factura, pero que por su formulación inicial parece que siempre quedarían preteridas al convento que tenía un papel principal en sus intereses. Se trataba de un hospital y una casa de doncellas.

Con respecto al primero parece que llegó a tener una sede, que en algún momento se pensaba podía ampliarse, y de ser así no podría en ningún caso suponer una molestia para la clausura de las dominicas:

«Ytem porque los dichos señores Pero Gonzales de León y doña María su Muger, por su devozion han hecho e fundado e quieren poblar e doctar junto al edificio de el dicho Monasterio un Ospital de la Madre de Dios se hasienta que en la obra que hagora esta hecha en el dicho hospital ni en la que hizieren de aquí adelante no se pueda hazer ni aga ventana ni saetera ni otro hedifizio que perjudique a la clausura de la casa de el dicho Monasterio e si en algún tiempo se hiziere que la Priora de el dicho Monasterio pueda mandar cerrar las ventanas de qualquier hedifizio que se hiziere en el dicho Ospital porque con esta condizion los dichos Señores fundadores hazen e dotan el dicho Ospital e esto se pondrá ansi en la erezion de el dicho Ospital».

La misma máxima se seguía para una Casa de Doncellas (Graña, 1994: 123). Sin embargo esta no estaba hecha, pues se pensaba que las mujeres ocuparían la casa vieja donde las monjas estuvieron hasta que el convento estuvo totalmente acabado. Esta opción por tanto impide que ser relacione a las doncellas con la elevada plétora de celdas que proponen en la escritura que cierran con los dominicos.

«Ytem que los dichos Señores Fundadores por su debuzion e para Gloria de Dios Nuestro Señor presan hazer (sic) una Casa de Donzellas en la casa donde agora están las monjas de el dicho Monasterio que para este efecto la Orden havra por bien e desde agora se declara que los dichos Señores fundadores e el dicho sucesor en la dicha su casa para hazer en ella la dicha Casa de Donzellas la qual tomen después de Acavado el edefizio de el dicho Monasterio, y pasadas las dichas monjas a él con tanto que el hedifizio a lo demás que en ellas se hiziere sea sin perjuicio de la clausura e onestidad e Recojimiento de el dicho Monasterio de la Madre de Dios». 


\section{MARGARITA TORREMOCHA HERNÁNDEZ \\ LA “COMPLICADA" HISTORIA DE UNA FUNDACIÓN. \\ DOMINICAS DE LA MADRE DE DIOS DE VALLADOLID (1550)}

A la denominación Casa de Doncellas no se le añade ninguna definición, que sin duda sería de gran interés. Los patronos sabían lo que querían y quiénes serían las destinatarias, pero en ningún caso acotan el tipo de mujeres que tendrían derecho a vivir en ella; si eran pobres o ricas, de la familia o de cualquier linaje, hasta qué edad, etc. Esta vaguedad, no obstante, no deja de indicar una menor preocupación por esta empresa, como se demuestra a la postre por los hechos.

Pero, las complicaciones familiares y económicas ulteriores negaron la viabilidad de estas dos propuestas: no se llegó a hacer el hospital y se olvida totalmente la casa de doncellas.

\section{COMPLICACIONES TRAS LA MUERTE DE LOS FUNDADORES. LAS HIJAS DE LOS PATRONOS}

Muertos los fundadores el patronato continuaba en la familia, según se deduce tanto del testamento de Don Pedro González como por lo firmado en la escritura con el Provincial de los dominicos:

«Ytem, que los dichos fundadores o qualquier de ellos que quedaren son e sean Patronos de el dicho Monasterio, y después de sus días Doña María de León su hija y los suzesores en su Casa Maiorazgo de las Villas de Padilla y el Villar y de las otras casas contenidas en el dicho Maiorazgo, y los tales suzesores en el sean Patronos de el dicho Monasterio para siempre jamás a los quales se les guardan todas las preeminencias que goza en estos Reynos los Patrones y fundadores de Monasterios».

Tras su muerte en 1558 estas fundaciones pasan a manos de sus descendientes. En su testamento reitera como lo comprado para el edificio y las huertas habían sido entregadas ya al convento por escritura, para «toda la casa y offiçinas». Sin embargo, aunque deseaba llevar él mismo a cabo todo lo proyectado en el seno de su matrimonio, de no poder ser espera y obliga a que lo hicieran sus sucesoras a su costa.

«E yo confio en la misericodia de dios y de su bendita madre y antes de mi fin y muerte lo haré y acabaré todo perfeçion pero que si lo que Dios no permita fallesciere antes de ser acabado quiero y es mi voluntad que la mejor partida de mis bienes se acabe todo ello como la dicha Doña María y yo estamos obligados a logar e acabar lo mejor fuere posible» ${ }^{24}$.

Para evitar conflictos con sus hijas establecía que todo lo que tanto él como su mujer habían dado a las monjas en ornamentos de seda y brocados, cálices, cruz

24. AGS, Cámara de Castilla, DIV, 37, 33. Borrador del testamento de Pedro González León, sin fecha. 
MARGARITA TORREMOCHA HERNÁNDEZ

LA “COMPLICADA” HISTORIA DE UNA FUNDACIÓN.

DOMINICAS DE LA MADRE DE DIOS DE VALLADOLID (1550)

procesional, joyas de plata y oro para el culto divino y la liturgia eran suyos y no se debían descontar de otras cantidades que se les hubieran ofrecido. Incluso, hecho el testamento, pensaba que si no moría les daría algunas cosas de valor más ( «Y en los días de su vida los ha de acrecentar así en ornamentos y joyas mucho más de lo que ahora tienen»). Pero todo ello estaría al margen y se les debería respetar, sin que fuera en detrimento de los 12.000 generosos ducados que se daban como dote para su hija María («quiero y es mi voluntad no se quente para cosa alguna al dicho monasterio en los 12.000 ducados que ansi se los an de dar ni en quenta de lo que se ha de gastar en la obra»).

Expuestas sus últimas voluntades en su legado, y acaecida su muerte, el 3 de noviembre de 1558, fueron sus hijas las que ejercieron la tarea de patronas del convento, además de tener que responder a las obligaciones que su padre había contraído, entre otros con el convento ${ }^{25}$.

La primogénita, con el mismo nombre que su madre, María, profesó en el convento de la Madre de Dios, donde fue muchos años Priora. La dote que dio era alta y «por razón de lo suso dicho tiene renunciado la legitima» de los bienes paternos que pudiera reclamar a la muerte de estos. De esa manera, su padre dejaba su herencia respaldada por el mayorazgo a una de sus hijas; la segunda.

La heredera de este fue Mencía de León, casada con D. Álvaro de Luna ${ }^{26}$, en la que recayó en principio el mayorazgo ${ }^{27}$, hasta su defunción ${ }^{28}$. Desconocemos la

25. ARCHV, Ejecutoria del pleito litigado por Mencía de León y Ana de León, hijas y herederas de Pedro González de León, con Gaspar de Anuncibay, como cesionario de la mujer e hijos de Alonso Berruguete, vecino de Valladolid, Cristóbal Lerman y Tomas Miller, de la compañia de los Fucares, el convento de Madre de Dios, orden de Santo Domingo, de Valladolid $y$ consortes, todos ellos acreedores a los bienes de Pedro González de León, sobre concurso de acreedores, Registro de Ejecutorias, Caja 1140,1 1568.

26. ARCHV, Ejecutoria del pleito litigado por Alonso de Castilla, y su curador en su nombre, vecino de Logroño (La Rioja), con Alonso de Luna y Mencia de León, su mujer, de la misma vecindad, sobre la ocupación de una casa y una buerta en dicha vecindad, Registro de Ejecutorias, Caja 1508,22 1584. Archivo Histórico Provincial de Valladolid (AHPV), Protocolos del Escribano Pedro de Arce, 373-21 (1572) y 373-83 (1573).

27. ARCHV, Real Provisión de emplazamiento dirigida a Mencía de León, vecina de Valladolid, y estante en Salamanca, a petición de Camilo Brebia de la compañia de los Lafetatis, para que presente testigos y escrituras originales en el pleito de ejecución de bienes que ambos tratan con Justo Balter, alemán de la compañía de los Fúcares, por una deuda de un cuento y varios miles de maravedies que heredó de su padre, el difunto Pedro González de León. Registros de Ejecutorias, Caja 980, 20, 1560.

28. ARCHV, Ejecutoria del pleito litigado por Cristóbal Hernán, Tomas Miller, alemanes, de la compañía de los Fúcares, Jorge Tulaime, flamenco, y Justo Balter, alemán, con Ana León, bija y heredera de Pedro González de León, Alvaro de Luna, como marido de Mencía de León y demás acreedores, sobre el remate en los bienes de Pedro González de León. Registro de Ejecutorias, Caja 1865,33, 1598. 


\section{MARGARITA TORREMOCHA HERNÁNDEZ \\ LA “COMPLICADA" HISTORIA DE UNA FUNDACIÓN. \\ DOMINICAS DE LA MADRE DE DIOS DE VALLADOLID (1550)}

fecha, aunque si sabemos que su testamento es de 25 de junio de 1563 . Fue entonces cuando Ana, la tercera de las hermanas pasó a ser la beneficiaria.

En esta época post-fundacional los conflictos heredados no fueron pocos, y las variaciones con respecto a lo dispuesto por Don Pedro tampoco. Mencía adopta ya la decisión de prescindir del Hospital de pobres que se había proyectado y edificado. Este - como dice en su testamento - lo consideraba sobre todo idea de su mujer, María Coronel,

«donde se curasen y albergasen pobres el qual ella y yo labramos y le hedificamos junto al monasterio de la Madre de Dios y para ayuda de la dottacion del dicho hospital su santidad nos hizo merced de [...] al dicho ospital para agora e por siempre jamas las dos tercias partes del beneficio de espartinas como según que las dichas bullas que por ello se despacharon e están en mi poder y lo an de dar después de mis días para siempre ${ }^{29}$.

Además de esta cantidad dejada para que en dicho hospital los pobres fueren bien curados, tuvo intención de dar $100.000 \mathrm{mrs}$. en un juro e censo, pero nada de ello se llevará a efecto por decisión de Mencía, que empieza a variar los planes paternos, pues acuerda que lo concedido en Espartinas por el Arzobispado de Toledo se dedique a dotar mejor el convento de la Madre de Dios:

«Ytem la dicha doña Menzia aplica y una maior dotazion de este combento cierta parte de los frutos de un Benefizio de Espartinas que es en el arzobispado de Toledo (el qual havia dejado su padre para dotar un hospital que se havia de fundar junto a este combento) el qual no tubo efecto, $y$ para anejarle a este referido comvento ympetro Bulla de su Santidad» ${ }^{30}$.

Por otra parte, como herederas, tanto ella como su hermana Ana prosiguieron ante los tribunales por la desavenencia que se había iniciado con Alonso Berruguete por el impago de un censo ${ }^{31}$.

Pero en lo concerniente al convento las querellas llegaron porque las monjas no veían concluir su construcción, que se había fijado para 1557. La comunidad pleiteó contra las dos hermanas para que, a costa de los bienes del mayorazgo que fundó su padre, acabasen la edificación, «en toda perfeccion el Dormitorio y demás ofizinas de este dicho comvento como estaban obligadas por los capítulos de la escriptura

29. AGS, Cámara de Castilla, DIV, 37, 33. Borrador Testamento de Pedro González León, $\sin$ fecha.

30. AHN, Secc. Clero Regular-secular, libro 17222, Libro Bezerro..., año de 1769.

31. ARCHV, Ejecutoria del pleito litigado por Alonso Berruguete, difunto y su procurador como señor de la instancia, con Mencía y Ana de León, hijas de Pedro González de León, sobre impago de un censo. Registros de Ejecutoria, Caja 1025, 10, 1562-7. 


\section{MARGARITA TORREMOCHA HERNÁNDEZ \\ LA “COMPLICADA" HISTORIA DE UNA FUNDACIÓN. \\ DOMINICAS DE LA MADRE DE DIOS DE VALLADOLID (1550)}

de fundación». Y fue el año 1562, muerta ya María, cuando las patronas recibieron de la Chancillería una sentencia en su contra.

Y, según el Libro Becerro, en virtud de esta sentencia Mencía otorgó una escritura de concierto con la Priora y religiosas de la Madre de Dios en que hacía renuncia de la casa vieja en la que se alojaron antes de edificar el monasterio de las monjas y a todo el derecho que ella tenía, con todo el terreno, para que lo pudieran incorporar al convento ${ }^{32}$.

Por una segunda cláusula de su escritura se dice: «...dio a dicho Comvento la Casa de el Ospital que llaman con todo lo perteneciente ha ella que estava inmediata a este dicho comvento para que usasen de ella como cosa suia propia». Es decir, que el edificio de lo que se denomina hospital - que no parece que lo fuera con ese uso - también pasaba a ser de las monjas. De esa manera se entiende que Mencía que no acababa las obras de construcción les dejaba a ellas la posibilidad de hacerlo, echando mano de esos dos bienes que como patrona les otorgaba.

La tercera y última de las hermanas recibió el nombre de Ana y vivía también en el convento con su hermana, aunque sin profesar ( Los señores fundadores tuvieron otra hija llamada doña Ana de León quien vivió en este comvento hasta que murió su hermana doña María») $)^{33}$. A ella, su padre en su testamento le deja para su dote 2.000 ducados, también respetando lo que estaba vinculado: «los quales sean dados e pagados de lo mejor de mis bienes que hazen fuera del dicho mayorazgo, al tiempo de mi fin y muerte» ${ }^{34}$.

Su trayectoria vital no queda definida como la de sus hermanas por tomar estado. Parece que había encontrado en el monasterio un refugio en una situación diferente, pues no era monja, ni hay constancia de que contrajese matrimonio. Como hija de los fundadores no se le negó un espacio para vivir, aunque no formara parte de una comunidad, con la que pronto tuvo desacuerdos. Tanto María como ella cobraban anualmente una renta sobre el servicio y montazgo de los ganados de estos reinos, de 150.000 maravedíes (Fernández, 1990: 193). Pero su estancia en el monasterio terminó - por propia decisión - con la muerte de María. Al producirse también el fallecimiento de Mencía quedó entonces como heredera y, sin duda alguna, fue la que dio el mayor giro, modificando los planes de sus padres los fundadores.

De manera poco locuaz se dice que «... por algunas desazones que hubo de tener con las religiosas se fue a vivir a la Villa y Corte de Madrid» ${ }^{35}$. Esta mudanza de ciudad y el convertirse en la propietaria del mayorazgo dejó en sus manos la ejecución de lo mandado por su padre y, en parte, el devenir del convento. Se puso

32. AHN, Secc. Clero Regular-secular, libro 17222, Libro Bezerro..., año de 1769, p. 38.

33. Ibid.

34. AGS, Cámara de Castilla, DIV, 37, 33. Borrador del testamento de Pedro González León, sin fecha.

35. AHN, Secc. Clero Regular-secular, libro 17222, Libro Bezerro..., año de 1769, p. 34. 


\section{MARGARITA TORREMOCHA HERNÁNDEZ \\ LA “COMPLICADA” HISTORIA DE UNA FUNDACIÓN. \\ DOMINICAS DE LA MADRE DE DIOS DE VALLADOLID (1550)}

en contacto con el Provincial de los dominicos y consiguió bula de Gregorio XIII, a solicitud del obispo de Palencia, Álvaro Mendoza, por la que se dispensaba a Ana, ya como heredera única y poseedora del mayorazgo, para que pudiera fundar un convento de la Orden, en lugar del Hospital que habían planeado María Coronel y su marido Pedro, con bienes agregados a su mayorazgo. No fundó sino que dotó una fundación en el convento de Santo Tomás de Madrid ${ }^{36}$ - hoy también desaparecido - que se había puesto en marcha el año 1565.

Doña Ana le otorgó en 1590 una destacada donación para la «erección, fundación y dotación del Convento... con su Iglesia, campanas, campanario, Sacristía, Claustro, Dormitorio, Refectorio, huerta con ortaliza y las demás oficinas necesarias, según y cómo en los demás monasterios de nra. Orden se estila», y además dándole a ese convento la idea que su madre había tenido para el de la Madre de Dios de Valladolid de contar - por su fundación - con un pequeño hospital para el cuidado de seis pobres ancianos (Viñals, 1899: 22; Rebollar, 2012: 68).

Este cambio dio lugar a un pleito dentro de la Orden, pues las monjas de la Madre de Dios reclamaron «se pagase quatrocientos ducados o quatrocientas fanegas de trigo en cada un año según lo capitulado en la escriptura de fundazion de este dicho comvento por haverse fundado con los vienes de dicho maiorazgo». Los jueces, nombrados por el Padre General, dieron sentencia condenatoria al convento de Santo Tomás para que diesen al de la Madre de Dios lo que reclamaban «y con todo lo que hubiese rentado en dicho tiempo lo qual les fue mandado pena de excomunicion». Ambas comunidades trataron y se pusieron de acuerdo en que la de Madrid diera a la de Valladolid, otorgando escritura de transación, 3.000 ducados «por una vez». $Y$ estos se recibieron en la Madre de Dios en febrero de $1613^{37}$. De tal manera que a comienzos del siglo XVII dio al traste de forma definitiva con la idea de construir y mantener un hospital de pobres.

Asimismo, como sucesora en el mayorazgo tuvo que defender los derechos de la familia ${ }^{38}$ y los suyos propios. Afrontó un largo proceso motivado por las

36. AGS. Contaduría Mayor de Hacienda, Juro a favor del colegio de Santo Tomás de Aquino, orden de Santo Domingo, de la villa de Madrid, 485,44 (100.000 mrs. de juro y cita de fundación de mayorazgo de Pedro González de León y María Fernández Coronel, de información en justificación de haber sucedido en dicho mayorazgo Ana de León y escritura de fundación y dotación de un hospital otorgada por doña Ana de León.); 485,50 (133.928 maravedís); 485,45 (375.000 maravedís), Testamento de Ana de León y testimonio de posesión del mayorazgo; 1430,18 (24.324 maravedís); 1427,13 (33.403 maravedís); 1426,32 (36.870 maravedís). Todos ellos de la segunda mitad del siglo XVI, demuestran la vinculación de Ana de León con este convento y hospital.

37. AHN, Secc. Clero Regular-secular, libro 17222, Libro Bezerro..., año de 1769, p. 34.

38. ARCHV, Real provisión dirigida a la Justicia de la ciudad y Obispado de Sigüenza (Guadalajara), a petición de Ana de León, vecina de Valladolid, hija de los difuntos Pedro González de León y María Hernández Coronel, por la que se ordena le metan en posesión de los bienes del mayorazgo que instituyeron sus padres que se encuentren en la ciudad y su jurisdicción, 
MARGARITA TORREMOCHA HERNÁNDEZ

LA “COMPLICADA” HISTORIA DE UNA FUNDACIÓN.

DOMINICAS DE LA MADRE DE DIOS DE VALLADOLID (1550)

reclamaciones de los acreedores de su padre, entre los que se encontraba la propia Ana. Ella había sido beneficiada por delante de los acreedores al manifestar que el sucesor del mayorazgo está obligado a gastar 8.000 ducados en el monasterio. Pero dado que a ella se le debían por vía de alimentos hasta la cantidad de 20.000 ducados, se le darían esos 8.000 , sin quitar nada del mayorazgo ni gravarle más. Los otros acreedores entendían que esa donación inter vivos que en su día se le hizo era para defraudarles. Finalmente, de entre ellos, el convento pide que se le den 800 fanegas de trigo con prioridad a otros acreedores. No obstante, el proceso fue lento y en 1598 todavía se sigue el pleito de los acreedores de su padre en el remate de sus bienes ${ }^{39}$.

Pero a finales del siglo y sobre todo por la decisión tomada por Ana que encontró respaldo en el Provincial de los dominicos y en el mismo papa, los proyectos de los patronos habían cambiado ya totalmente y ella está volcada en otra empresa: en el convento de Santo Tomás de Aquino de Madrid ${ }^{40}$, que se convirtió en el sucesor en los bienes del mayorazgo de Pedro González.

\section{CONSIDERACIONES FINALES}

En esta historia de la primera etapa - la de la fundación - del convento de la Madre de Dios, la prioridad está en los intereses de los patronos, que habían impulsado el proyecto con su iniciativa y con su economía posibilitan la aparición del convento. Son además, en este caso, los que adoptando en origen un patronazgo pleno, definen la estructura conventual.

A pesar del papel fundamental de los fundadores su determinación no es suficiente, porque es preciso que el monasterio fundado cobije a unas monjas que se pongan bajo las reglas y el control de una orden religiosa. No obstante, en la historia esencial de este convento, la orden dominica no acarreó problemas, porque de una forma u otra, en un convento femenino o masculino, en Valladolid o en Madrid, se vio beneficiada por las dos generaciones sucesivas de esta familia fundadora.

En sus primeros años, casi media centuria, los problemas llegaron de la mano de las patronas, descendientes de los fundadores, una familia de mercaderes de origen judío, que hablan de sus devociones en general y, en singular, a la Madre de Dios. Una familia que sigue el camino trazado por la aristocracia y por la nobleza de

entre ellos 1.149 maravedíes anuales de juro situado sobre la martiniega de Molina de Aragón (Guadalajara), y el heredamiento de Padilla que adquirieron del Marqués de Astorga. Registro de Ejecutorias, Caja 1271,77, 1573.

39. ARCHV, Ejecutoria del pleito litigado por Cristóbal Hernán, Tomas Miller, alemanes, de la compañía de los Fúcares, Jorge Tulaime, flamenco, y Justo Balter, alemán, con Ana León,.... Registro de Ejecutorias, Caja 1865,33, 1598.

40. ARCHV, Ejecutoria del pleito litigado por Gaspar de Anuncibay,..., ARCHV, Registro de Ejecutorias, Caja 1926,100, 1601. 


\section{MARGARITA TORREMOCHA HERNÁNDEZ \\ LA “COMPLICADA" HISTORIA DE UNA FUNDACIÓN. \\ DOMINICAS DE LA MADRE DE DIOS DE VALLADOLID (1550)}

nuevo cuño, que entre sus patrones de conducta incluyen este tipo de padrinazgo de forma sistemática. Ellos escogen la Orden a la que también se sentían unidos. Si bien, el motivo de la fundación tampoco se explicita más. En aquellos tiempos sacralizados seguramente no parecería necesario.

Por tanto, en el ánimo de los patronos estuvieron las dos claves que movieron las fundaciones de monasterios, sobre todo los femeninos. Por encima de todo estaba la buena acción que les ayudaría en la vida futura a salvar su alma, pues en la mundana habían obtenido buenas ganancias con los negocios del cabeza de familia. Y esas oraciones y sus sepulcros estarían organizados como lo hacía la nobleza, a la que se igualaba con esta iniciativa, como lo había hecho al constituir un mayorazgo y gozar de un señorío. Pero los pilares fueron dos. Por una parte, el tener un lugar donde descansaran sus restos y donde recibieran sus almas la oración diaria de las monjas (aunque este apartado de fundamental observancia fue retocado poco después) ${ }^{41}$. El edificio del monasterio adquiere un protagonismo singular, y dentro de él especialmente la capilla y los enterramientos. Un espacio arquitectónico destacado, con materiales de calidad e incluso de lujo, donde se custodian sus estatuas de bulto, compuestas en el taller más prestigioso.

En segundo lugar dar acomodo a una de sus descendientes. La opción de que su primogénita profesase no solo sin problemas, sino en un cenobio en el que pronto sería la priora y con el tiempo otra serie de mujeres, vinculadas a la familia generalmente, que podrían profesar sin dote, y entre ellas las primeras sus sobrinas, hijas de su hermanas, sin patrimonio para casar, a las que les ofrece una plaza desde su testamento.

Así pues, fuesen reyes, nobles u hombres de negocios las razones fueron las mismas, y en los intereses manifestados desde los orígenes de esta fundación quedan claros. Desde la otra perspectiva las monjas que contaban con un patrón se veían más seguras y protegidas. Pero, a las primeras voluntades de los fundadores en los orígenes del convento vallisoletano de Madre de Dios se fueron planteando problemas, que dieron lugar a conflictos, haciendo que se modificaran los empeños originales, pero pudiendo ser superados sin que se tuviera que cerrar el convento o transferirlo a otros patronos como ocurrió en esta misma ciudad con otros monasterios femeninos ${ }^{42}$.

41. «Ytem que por quanto en un capítulo de la Fundazion esta capitulado se haian de dezir cada dia dos misas cantadas en la Yglesia de este comvento por las Animas de los fundadores una en e dia y otra de nuestra Señora y dos Responsos cantados que de allí adelante no tengan obligazion de mandar dezir más que una misa cantada y un responso. Paso esta Escriptura ante Juan de Rozas escribano en Valladolid a 4 de nobiembre de $1562 \ldots$... AHN, Secc. Clero Regular-secular, libro 17222, Libro Bezerro..., año de 1769.

42. Es el caso del Monasterio vallisoletano de Porta Coeli, de dominicas en su segunda etapa, cuando Don Rodrigo Calderón se lo compró a su primera fundadora, Mariana Cortés de Gallo, que lo había puesto en manos de las franciscanas. Dato aportado a la autora por Silvia de la Fuente Pablos. 


\section{MARGARITA TORREMOCHA HERNÁNDEZ \\ LA "COMPLICADA" HISTORIA DE UNA FUNDACIÓN. \\ DOMINICAS DE LA MADRE DE DIOS DE VALLADOLID (1550)}

En esta etapa post-fundacional, fue cuando la última de sus hijas, la que se convierte en heredera del mayorazgo modifica - con aprobación de la orden dominica- los planes paternos para poner todas sus miras en un convento dominico pero masculino, en Madrid, olvidando otras dos empresas benéfico - asistenciales que también sus progenitores habían proyectado además del convento. Hospital y casa de doncellas no llegaron a tener vida. Pero si el convento de la Madre de Dios, que vivió desde sus claustros estas variaciones de la hija más longeva y enigmática de los León-Coronel.

Esos giros sobre las propuestas originarias de los fundadores nos llevan a plantearnos si tras los primeros años se siguió manteniendo un patronato pleno. $\mathrm{O}$ si por la falta de descendientes tras la muerte de Ana de León, se perdió este carácter.

Poco hemos sabido sobre este monasterio desaparecido a comienzos del siglo XIX, cuyas últimas monjas, con parte de su archivo, se fueron a incrementar la comunidad del convento de Porta Caeli, del que fue patrón Don Rodrigo Calderón. Hasta que podamos conocer más de este claustro, estudiemos las capellanías que albergó el convento y si fueron o no de patronato externo a la comunidad y también el de las memorias perpetúas que en él se fundaron, solo podremos abogar por que se mantuvo al menos el patronato funerario y litúrgico.

La etapa fundacional y post-fundacional es pues la del protagonismo de fundadores y patronos, aunque también debió ser compleja en la puesta en marcha de la vida de espiritualidad de unas mujeres que se estrenaban como religiosas, que además inauguraban un convento y todo ello con el cambio que el Concilio de Trento llevaba a los monasterios femeninos. La vida conventual femenina no se puede restringir a un único estándar. Hubo una gran diversidad de modelos, algunos marcados por las condiciones personales, pero también por las características del convento que empiezan desde su fundación y por sus patronos.

\section{BIBLIOGRAFÍA}

AGAPITO Y REVILLA, J. (1937/2004). Las calles de Valladolid, Nomenclator histórico, Valladolid, Valladolid: Editorial Maxtor Librería.

ALONSO RUIZ, B., GÓMEZ MARTÍNEZ, J., POLO SÁNCHEZ, J. J., SAZATORNIL RUIZ, L., VILLASEÑOR SEBASTIÁN, F. (Eds.), (2018). La formación artística: creadores-historiadores-espectadores, Santander.

ANIZ IRIARTE, OP., C. (1998). Las Lauras. Reforma y recolección dominicana (s. XVII), Salamanca: San Estéban.

ANTOLÍNEZ DE BURGOS, J. (1887). Historia de Valladolid, Valladolid.

DE ARRIAGA, G. (1928), Historia del Colegio de San Gregorio de Valladolid, ed. Corregida y aumentada por el P. M. Hoyos OP., Valladolid. 


\section{MARGARITA TORREMOCHA HERNÁNDEZ \\ LA “COMPLICADA" HISTORIA DE UNA FUNDACIÓN. \\ DOMINICAS DE LA MADRE DE DIOS DE VALLADOLID (1550)}

ATIENZA LÓPEZ, A. (2008). La apropiación de patronatos conventuales por nobles y oligarcas en la España Moderna. Investigaciones históricas: Época moderna y contemporánea, 28, 79-116.

ATIENZA LÓPEZ, A. (2009). Fundaciones y patronatos conventuales y ascenso social en la España de los Austrias. En E. Soria Mesa, J. J. Bravo (Coord.), Las élites en la época moderna: la monarquía española, Vol. 4 (Cultura), 37-54.

ATIENZA LÓPEZ, A. (2012). Los que fracasaron: fundaciones y fundadores frustrados. La otra cara de la expansión conventual en la España moderna. En E. Soria Mesa, A. J. Díaz Rodríguez (Coord.), Iglesia, poder y fortuna: clero y movilidad social en la España Moderna, Granada: Comares, 89-114.

ATIENZA LÓPEZ, A. (2013). Una España llena de conventos. Fundaciones y fundadores en la Edad Moderna. Cuadernos najerillenses, I (1) 19-24.

ATIENZA LÓPEZ, A. (2016). Conventos y patronos: cuestiones sobre las relaciones de patronazgo conventual en la España moderna. En J.M. Imizcoz, A. Artola (Coord.), Patronazgo y clientelismo en la monarquía hispánica: (siglos XVI-XIX), Universidad del País Vasco, 109-134.

BARRIO GOZALO, M. (2016). Religión y sociedad en Valladolid y su obispado (15951851), Valladolid: Ayuntamiento de Valladolid.

CATALÁN, E. (2004). El derecho de patronato y el régimen beneficial de la Iglesia española en la Edad Moderna. Hispania Sacra, 56, 135-167.

ESTEBAN PIÑEIRO, M. (2000). Las medidas en la época de Felipe II. La uniformación de las medidas. En Museovirtual. CSIC.

FERNÁNDEZ MARTÍN, L. (1990). La casa de la lnquisición de Valladolid. Investigaciones históricas: Época moderna y contemporánea, 10, 189-202.

FERNÁNDEZ DEL HOYO, M. A. (1998). Conventos desaparecidos de Valladolid. Patrimonio perdido, Valladolid: Ayuntamiento de Valladolid.

GONZÁLEZ GARCÍA-VALLADOLID, C. (1893). Datos para la Historia Biográfica de Valladolid (2 tomos), Valladolid.

GRAÑA CID, M. del M. (1994). Mujeres y educación en la Prerreforma castellana: los colegios de doncellas. Las sabias mujeres: educación, saber y autoría. Siglos III-XVII, Madrid.

GRAÑA Cid, M. del M. (2012). Poder nobiliario y monacato femenino en el tránsito a la Edad Moderna (Córdoba, 1495-1550). Cuadernos de historia moderna, 37, 43-72.

HOYOS, P. M., OP., (1968). Registro Historial de la Provincia de España, Tomo II, Conventos de la Segunda Orden, Pamplona: Ed. San Estéban.

LÓPEZ EL MONOPOLITANO, J. (1613). Tercera Parte de la Historia General de Sancto Domingo y de su Orden de Predicadores, Salamanca: San Esteban.

MARTÍ Y MONSÓ, J. (1898-1901). Estudios histórico-artísticos: relativos principalmente a Valladolid, basados en la investigación de diversos archivos, Valladolid-Madrid.

MARTÍN POSTIGO, M.S. (1982). Tras las huellas de Fray Vicente Velázquez de Figueroa. En Discurso de recepción en la Real Academia de Bellas Artes de la Purísima Concepción. 


\section{MARGARITA TORREMOCHA HERNÁNDEZ \\ LA “COMPLICADA” HISTORIA DE UNA FUNDACIÓN. \\ DOMINICAS DE LA MADRE DE DIOS DE VALLADOLID (1550)}

NIEVA OCAMPO, G. (2007). Servir a Dios con quietud», la elaboración de un modelo regular femenino para las dominicas castellanas a mediados del siglo XVI. Hispania Sacra, 59, 119, 163-196.

REBOlLAR ANTÚNEZ, A. (2012). El Colegio Dominico de Atocha en Madrid. Una propuesta para su reconstrucción. Boletín de la Real Academia de Bellas Artes de la Purísima Concepción, 47, 67-92.

REY CASTELAO, O. (2009). Las instituciones monásticas femeninas, ¿centros de producción? Manuscrits: Revista d'història moderna, I, 27, 59-76.

SÁNCHEZ GÓMEZ, J. (1989). De minería, metalúrgica y comercio de metales: La minería no férrica en el reino de Castilla (1450-1610), Vol 102, n 1 , Salamanca.

SÁNCHEZ HERNÁNDEZ, L. (1998). Las variedades de la experiencia religiosa en las monjas de los siglos XVI y XVII. Arenal, 5, 69-105.

SANGRADOR VÍTORES, M. (1851-1854). Historia de la muy noble y leal ciudad de Valladolid, desde su más remota antigüedad hasta la muerte de Fernando VII, Valladolid: Imprenta de D. M. Aparicio, 326-327.

SORIANO TRIGUERO, C. (2000). Trento y el marco institucional de las órdenes religiosas femeninas en la Edad Moderna. Hispania Sacra, 52, 106, 479-494.

TORREMOCHA HERNÁNDEZ, M. (1991). Ser estudiante en el siglo XVIII. La Universidad vallisoletana de la Ilustración, Valladolid: Junta de Castilla y León.

TORREMOCHA HERNÁNDEZ, M. (2003). Mujeres ilustres vallisoletanas, Valladolid: Ayuntamiento, 91-94.

TORREMOCHA HERNÁNDEZ, M. (2014). De la Mancebia a la Clausura. La casa de Recogidas de Magdalena de San Jerónimo y el convento de San Felipe de la Penitencia (Valladolid, siglos XVI-XIX), Valladolid: Secretariado de Publicaciones Universidad de Valladolid. Colección: Estudios y Documentos.

TORREMOCHA HERNÁNDEZ, M. (2019). Cárcel de mujeres en el Antiguo Régimen. Teoría y realidad penitenciaria de las galeras, Madrid: Dykinson.

TORREMOCHA HERNÁNDEZ, M. (2019). «Monjas Dominicas. El siglo XVII en el desaparecido convento de la Madre de Dios de Valladolid», Alfredo Martín García y María José Pérez Álvarez (coords.), Religiosidad y reforma católica en el Noroeste de la península ibérica: Siglos XV-XIX. Madrid, Sílex, 1031-131.

VIÑALS, F. (1899). Santo Tomás de Madrid. Historia Manuscrita é Inédita de este convento dominicano por el P. Fr. Antonio Martínez Escudero, Madrid. 